\title{
The Consolidation of Multistate Litigation in State Courts
}

\section{George T. Conway III}

In recent years, multistate litigation ${ }^{1}$ has grown spectacularly in both cost and complexity. In particular, the expense of mass tort litigation, which commonly involves dozens of closely related lawsuits brought by citizens of many states, has reached staggering levels. ${ }^{2}$ The cost of litigating these claims often exceeds the sums that are ultimately paid to plaintiffs. ${ }^{3}$ Inefficiencies and costs associated with such multistate, multiparty litigation have inspired proposals for legislative and judicial reforms ranging from suggested changes in the substantive law ${ }^{4}$ to calls for more extensive use of joinder or consolidation devices. ${ }^{5}$

1. In this Note, "multistate litigation" refers to litigation involving civil actions that (1) share at least one common issue of fact, and (2) have been filed in more than one court, state or federal. This definition thus includes related civil actions filed in more than one judicial district (state or federal) within a single state, even though such litigation would, strictly speaking, be "multidistrict," not "multistate."

2. See, e.g., Rosenberg, The Causal Connection in Mass Exposure Cases: A "Public Law" Vision of the Tort System, 97 HARv. L. REv. 851, 852 (1984) (individual trials of mass tort cases would cost hundreds of millions of dollars); Transgrud, Joinder Alternatives in Mass Tort Litigation, 70 CoRNELL L. Rev. 779, 781 (1985) (same).

3. This has been particularly evident with tort claims involving asbestos exposure. One study of asbestos litigation found that, on average, the net compensation received by plaintiffs, after deducting plaintiff' litigation expenses, constituted $37 \%$ of the sum of defense litigation costs and the total compensation paid to plaintiffs by defendants and insurers. J. KAKALIK, P. EBENER, W. FELSTINer \& M. Shanley, Costs of Asbestos Litigation vii (1983) [hereinafter Costs of Asbestos LitigaTION]. Estimates of the liabilities and costs of asbestos litigation range in the billions of dollars. See, e.g., P. MacAvoy, The Economic Consequences of Asbestos-Related Disease 69 (Yale School of Organization and Management Working Paper No. 27, 1982) (present value in 1980 dollars of future asbestos-related liability and defense costs estimated at $\$ 38.2$ billion).

4. See, e.g., S. 100, 99th Cong., 2d Sess., 132 Cong. Rec. S5106-07 (1986) (Reagan administration proposal to establish fault-based national products liability law); Tydings, Air Crash Litigation: A Judicial Problem and a Congressional Solution, 18 AM. U.L. REv. 299, 311-12 (1969) (urging passage of federal legislation governing liability and jurisdiction in aviation and space accidents); Comment, Relief for Asbestos Victims: A Legislative Analysis, 20 HARv. J. ON LEGIS. 179, 191-200 (1983) (advocating federal legislation creating administrative compensation system for victims of asbestos exposure); Note, The Case for a Federal Common Law of Aircraft Disaster Litigation: $A$ Judicial Solution to a National Problem, 51 N.Y.U. L. REv. 231 (1976); Note, Mass Tort Litigation: A Statutory Solution to the Choice of Law Impasse, 96 YALE L.J. 1077 (1987) (proposing federal choice of law statute governing mass tort cases).

5. See, e.g., Miller \& Crump, Jurisdiction and Choice of Law in Multistate Class Actions After Phillips Petroleum Co. v. Shutts, 96 YALE L.J. 1, 75-78 (1986) (advocating legislation providing for multiparty, multistate federal jurisdiction, mandatory joinder, and nationwide service of process); Mullenix, Class Resolution of the Mass-Tort Case: A Proposed Federal Procedure Act, 64 TEx. L. REv. 1039, 1060-99 (1986) (presenting draft statute requiring federal class action treatment of mass injury litigation involving 1000 or more potential claimants); Transgrud, supra note 2, at 831-49 (arguing for more extensive use of joinder to facilitate discovery, encourage settlements, and produce 
One product of reform that has proven particularly successful is the Judicial Panel on Multidistrict Litigation. Empowered by 28 U.S.C. $\S$ 1407 to transfer related civil actions filed in federal courts to a single district for consolidated proceedings, ${ }^{8}$ the Judicial Panel has used its authority both to conserve federal judicial resources and to reduce the danger of unfairly inconsistent adjudication in related multistate, multiparty cases. The ability of the Judicial Panel to foster efficiency and fairness in multistate, multiparty litigation remains limited, however, because the Panel currently lacks the power to remove cases from, and to transfer cases to, state courts. To remove this limitation, this Note proposes that Congress confer upon the Panel discretionary authority to direct litigation to and from state courts. The Note suggests factors that the Panel should consider before ordering consolidation in state courts, and argues that a necessary factor should be a likelihood that, after transfer, the substantive law of the transferee jurisdiction will govern much of the litigation. The Note concludes that a grant to the Panel of power over litigation in state courts would be constitutionally permissible.

\section{The Problem: Multistate Gases in State Courts}

\section{A. Efficiency and Fairness in Multistate Cases}

When properly used, joinder or consolidation devices ${ }^{7}$ can make multiparty, multistate litigation both fairer and more efficient. Joinder or consolidation can promote efficiency by reducing or eliminating the duplication of effort that inheres in the independent prosecution of parallel claims. For example, both can vastly reduce the cost of litigation by eliminating duplicative discovery and trials, which not only waste scarce judicial resources but also inflict unnecessary inconvenience upon witnesses

fairer trials of punitive damages claims); Williams, Mass Tort Class Actions: Going, Going, Gone?, 98 F.R.D. 323, 325-36 (1983) (advocating greater use of class actions in adjudicating mass tort claims); Comment, Federal Mass Tort Class Actions: A Step Toward Equity and Efficiency, 47 ALB. L. REv. 1180 (1983) (same).

6. 28 U.S.C. $\S 1407$ (1982).

7. Although "consolidation of cases under FED. R. Crv. P. 42(a) is functionally equivalent to joinder of the claims for most purposes," Transgrud, supra note 2 , at $785 \mathrm{n} .25$, consolidation and joinder are distinct concepts. "[C]onsolidation is permitted as a matter of convenience and economy in administration, but [unlike joinder] does not merge the suits into a single cause, or change the rights of the parties, or make those who are parties in one suit parties in another." Johnson v. Manhattan Ry. Co., 289 U.S. 479, 496-97 (1933) (footnote omitted). Nonetheless, in consolidated mass tort cases, trial courts "often allow litigants to proceed in most significant respects as if the claims were joined." Transgrud, supra note 2, at 785 n.25. Federal trial courts handling consolidated mass tort litigation often permit joint discovery and joint trials of common issues, and may even appoint "lead" counsel to represent groups of claimants. Id.; see also MANUAL For CoMplex LiTigation, SeCond $§ 20.22$ (1985) (recommending that courts handling complex cases "select and empower, by court order if necessary, one or more attorneys to act on behalf of other counsel and parties"). 
and parties. ${ }^{8}$ In addition, joinder or consolidation may reduce the expense of litigation by fostering settlements. ${ }^{\ominus}$

Joinder of related claims or consolidation of related actions promotes fair adjudication by reducing the potential for both conflicting pretrial rulings and inconsistent judgments. ${ }^{10}$ The danger of inconsistent adjudication is particularly compelling when plaintiff class actions involving similar or identical claims are brought in different courts. Because such parallel class actions can produce conflicting or overlapping class definitions by courts of different jurisdictions, an individual can become a member of two or more class actions that present identical claims. ${ }^{11}$ When such an overlap occurs, the individual's claims become subject to an "irrational resolution by a race to judgment." 12 Even if absent class members are permitted to "opt out" of any or all of the parallel lawsuits, no guarantee exists that the actions of many individual class members choosing to opt out will resolve the conflict or eliminate the overlap. ${ }^{13}$ The problems resulting from competing class actions may best be solved by consolidation of the actions in one court. ${ }^{14}$

\section{B. The Judicial Panel on Multidistrict Litigation}

Within the federal court system, the problems of duplicative litigation can be mitigated by the transfer of related lawsuits under 28 U.S.C. $\S$ 1407 by the Judicial Panel on Multidistrict Litigation. ${ }^{15}$ Created by Con-

8. See, e.g., Cahn, A Look at the Judicial Panel on Multidistrict Litigation, 72 F.R.D. 211, 221 (1977); Note, Class Certification in Mass Accident Cases Under Rule 23(b)(1), 96 HaRv. L. Rev. 1143, 1144 (1983).

9. See, e.g., W. Turley, Aviation Litigation $\S 12.04$, at 429-30 (1986).

10. See, e.g., Note, supra note 8, at 1144; see also infra note 12.

11. "Among the hypothetical parade of horribles which can be projected is the scenario in which 50 competing, national, multistate opt-out class actions are brought on the same claims and all members remain silent in response to the fifty notices." Kennedy, Class Actions: The Right To Opt Out, 25 ARIz. L. REV. 3, 81 (1983).

12. Miller \& Crump, supra note 5, at 70. Professors Miller and Crump observe that a race to judgment among competing class actions would encourage litigants to engage in unseemly tactical behavior. "For example, defendants could forum-shop by delaying or accelerating particular actions. Plaintiffs could collude with similarly aligned parties in 'stalking horse litigation,' diverting their opponents' attention or seeking collateral advantages such as the cumulative benefits of inconsistent discovery rulings." Id. at 24 (footnotes omitted).

13. See Manual. for Complex Litigation $\$ 5.40$ (5th ed. 1982) (conflict may "in theory" be resolved by choices of potential plaintiffs); Miller \& Crump, supra note 5, at 23-24 (discussing possibility of competing actions with "passive class[es] virtually intact in each").

14. See, e.g., Manual for Complex Litigation $\$ 5.40$ (5th ed. 1982) (recommending transfer of related class actions to single district to avoid conflict); Comment, The Experience of Transferee Courts Under the Multidistrict Litigation Act, 39 U. CHI. L. REv. 588, 604 (1972) (same); cf. In re Plumbing Fixture Cases, 298 F. Supp. 484, 493 (J.P.M.D.L. 1968) (multidistrict transfer intended by Congress to eliminate "chaos" of conflicting class action determinations).

15. For a comprehensive overview of the work of the Judicial Panel, see 15 C. WRIGHT, A. Milleer \& E. Cooper, Federal Practice and Procedure \$§ 3861-3868 (1986) [hereinafter 15 Wright \& Miller]. Other helpful discussions about the Judicial Panel include D. HerR, MuLTIDISTRICT LITIGATION (1986); Cahn, supra note 8; Herndon \& Higginbotham, Complex Multidis- 
gress in $1968{ }^{16}$ the Panel consists of seven federal district and circuit judges who are selected by the Chief Justice of the United States. ${ }^{17}$ The Panel is authorized by section 1407 to transfer civil actions that are pending in different federal district courts to a single district for coordinated pretrial proceedings. ${ }^{18}$ Transfer of civil actions may be ordered by the Panel either sua sponte or on the motion of any party, and is permitted when (1) "actions involving common questions of fact are pending in different districts"; (2) the transfer "will be for the convenience of parties and witnesses"; and (3) the transfer "will promote the just and efficient conduct" of the litigation. ${ }^{19}$ In creating the Panel and setting forth these standards for transfer, Congress sought to promote judicial economy and to minimize the "possibility for conflict and duplication in discovery and other pretrial procedures in related cases." 20

The work of the Judicial Panel has been widely hailed for its success in accomplishing these goals. ${ }^{21}$ Multidistrict transfer under section 1407 has promoted judicial economy by facilitating the termination of litigation in transferee courts through settlements and summary judgments. ${ }^{22}$ Additionally, the Judicial Panel and transferee courts have used section 1407 in conjunction with statutory provisions on change of venue to consolidate lawsuits for trial as well as for pretrial proceedings. ${ }^{23}$ Although consolida-

trict Litigation-An Overview of 28 U.S.C.A. \$ 1407, 31 BAYLOR L. REv. 33 (1979); Howard, A Guide to Multidistrict Litigation, 75 F.R.D. 577 (1977); Weigel, The Judicial Parel on Multidistrict Litigation, Transferor Courts, and Transferee Courts, 78 F.R.D. 575 (1978); Note, The Judicial Panel and the Conduct of Multidistrict Litigation, 87 HARv. L. REv. 1001 (1974).

16. Section 1407 was enacted at least in part as the result of the experiences of the federal courts during the 1960's in handling the electrical equipment antitrust cases, which involved more than 1800 separate but closely related civil damage actions filed in 33 courts. See 15 WRIGHT \& MILLER, supra note $15, \$ 3861$; Note, supra note 15 , at 1001 \& n.1.

17. 28 U.S.C. $\$ 1407$ (d) (1982).

18. Id. $\S 1407(\mathrm{a})$.

19. Id.

20. H.R. REP. No. 1130, 90th Cong., 2d Sess. 2, reprinted in 1968 U.S. Code Cong. \& AdMIN. NEwS 1898, 1899-1900.

21. See, e.g., D. Herr, supra note 15, at xix ("The result of the Panel's activities has been litigation that is both more manageable by the courts and more expeditiously resolved for the litigants."); Cahn, supra note 8, at 221 (noting "salutary" effects of multidistrict transfer); Herndon, Section 1407 and Antitrust Multidistrict Litigation-The First Decade, 47 ANTITRUST L.J. 1161, 1179 (1979) ("[S]ection 1407 has a decade of success on which can be built techniques to cope with the problems to be raised by multidistrict antitrust litigation in the next decade."); Weigel, supra note 15, at 585 (multidistrict transfer has "contributed immeasurably to the public welfare and to the capacity of the federal judiciary to carry out its ever increasing burden of litigation"); Comment, supra note 14, at 588, 611 (calling multidistrict transfer "a valuable but incomplete device" and urging that Congress expand Panel's authority by allowing transfer "for purposes of trial . . . without regard to venue").

22. See D. HERR, supra note $15, \S 9.9 .1 ; 15$ WRIGHT \& MilleR, supra note $15, \S 3866$.

23. See, e.g., Transgrud, supra note 2, at 804-09; Note, supra note 15 , at 1017 . Courts have consistently held that a $\$ 1407$ transferee court may transfer multidistrict litigation to itself for trial under 28 U.S.C. $\$ 1404($ a). See, e.g., In re Fine Paper Antitrust Litig., 685 F.2d 810, 819-20 (3d Cir. 1982), cert. denied, 459 U.S. 1156 (1983). This practice has also been approved by the Judicial Panel. See R.P.J.P.M.D.L. 11(b); infra note 59 and accompanying text. 
tion for trial almost certainly defies both the letter of section $1407^{24}$ and the intent of its drafters, ${ }^{25}$ the practice fosters fairness in adjudication by promoting consistent results in related cases. ${ }^{26}$ Consolidation for trial also enhances judicial economy by eliminating the delay and duplication of effort that would result if each transferred case were remanded to its original district for trial. ${ }^{27}$ In addition, the transferee judge can take advantage of the expertise she develops in managing the pretrial proceedings to try the transferred cases quickly and effectively. ${ }^{28}$

\section{Multistate Litigation in State Courts}

The Judicial Panel has no power over litigation in state courts, which today manage and adjudicate a large and ever-increasing number of mass tort and other complex, multiparty cases. ${ }^{29}$ Many of these cases neither

24. "Each action so transferred shall be remanded by the panel at or before the conclusion of such pretrial proceedings to the district from which it was transferred unless it shall have been previously terminated ...." 28 U.S.C. § 1407(a) (1982).

25. See, e.g., Transgrud, supra note 2 , at 806-08 (reviewing legislative history of $\S 1407$ ); see also H.R. REP. No. 1130, supra note 20, at 4; Levy, Complex Multidistrict Litigation and the Federal Coutts, 40 Fordham L. Rev. 41, 64 \& n.142 (1971).

26. See, e.g., In re Multidistrict Civil Actions Involving the Aircrash near Duarte, Cal., on June 6, 1971, 357 F. Supp. 1013, 1016 (C.D. Cal. 1973) (ordering $\$ 1404$ (a) transfer to avoid "different results in different districts").

27. See Note, supra note 15, at 1036 (noting that "trial of complex common issues in one court is frequently practical and efficient," and advocating revision of $\S 1407$ to allow transfer for trial); Comment, supra note 14 , at 588,611 (same).

28. A particularly dramatic recognition of the importance of this consideration came in Pfizer, Inc. v. Lord, 447 F.2d 122 (2d Cir. 1971). Pfizer involved 31 civil antitrust actions for which pretrial proceedings under $\S 1407$ (a) were conducted in the Southern District of New York by a district judge who had been sitting by designation under 28 U.S.C. $\S 292$. Because the judge found that he could not remain in New York for the duration of the subsequent trials, he transferred the actions under $\S 1404$ (a) to his home district, the District of Minnesota, for trial. Defendants opposing the transfer were denied a writ of mandamus by the Second Circuit, which held that the district judge's action was "fully justified under the circumstances." 447 F.2d at 125. In emphasizing the "unusual circumstances of this case," the appeals court relied upon the district judge's belief "that because of the complexity of these cases the interests of judicial efficiency made it highly desirable that the judge who conducted the pretrial proceedings continue as the trial judge . ..." Id.

29. State courts, for example, have played a significant role in adjudicating asbestos-related tort claims. Of the 17,120 asbestos exposure cases pending against Johns-Manville at the time of its bankruptcy filing, 11,143-nearly two-thirds-had been brought in state courts. Parrish, Asbestos Litigation-Dimensions of the Problem, STate CT. J., Winter 1984, at 5. One study has shown that, of asbestos-related lawsuits terminated before 1982, nearly half had been brought in state courts. CosTs of Asbestos Litigation, supra note 3, at 13. In California, Pennsylvania, and South Carolina, over two-thirds of such cases had been filed in state courts. Id.

A notable example of the successful handling of complex, multiparty cases by a state court is the settlement of the litigation spawned by the tragic collapse in July 1981 of the "skywalks" at the Hyatt Regency Hotel in Kansas City, Missouri. Because the certification of a mandatory class action in federal court was overturned by the Eighth Circuit, see In re Federal Skywalk Cases, 680 F.2d 1175 (8th Cir.), vacating 93 F.R.D. 415 (W.D. Mo.), cert. denied, 459 U.S. 988 (1982), "the full responsibility of mass tort management" was "effectively placed" on the state trial court. Wright \& Colussi, The Successful Use of the Class Action Device in the Management of the Skywalks Mass Tort Litigation, 52 UMKC L. REv. 141, 143 (1984). By certifying a voluntary class action, the state court facilitated a settlement of much of the state court litigation. See Student Project, A Case Study in Mass Disaster Litigation, 52 UMKC L. Rev. 151, 171-72 (1984). The state court settlement provided the 
involve questions of federal law nor meet the statutory criteria for federal diversity jurisdiction, and thus cannot be heard in a federal court. ${ }^{30} \mathrm{Ac}-$ cordingly, related cases filed in courts of different states often cannot be consolidated in any court for either pretrial proceedings or trial, ${ }^{31}$ resulting in both waste of judicial resources and potentially inconsistent adjudication.

The inefficiency and inequity of such duplicative litigation in state courts has taken on increased significance in light of the Supreme Court's recent holding in Phillips Petroleum Co. $v$. Shutts, ${ }^{32}$ a decision that is likely to increase the amount of multistate, multiparty litigation brought in state courts. Shutts held that in a class action, state courts may assert personal jurisdiction over absent plaintiffs who lack "minimum contacts" with the forum state. ${ }^{33}$ "[T]o bind an absent plaintiff," ruled the Court, a state court need only afford the absent plaintiff "notice," "an opportunity to be heard and participate in the litigation, whether in person or through counsel," "an opportunity to remove himself from the class," and adequate representation. ${ }^{34}$ By holding that the judgments of state courts may bind class members who lack contacts with the forum, Shutts has removed a substantial barrier to the litigation of nationwide class actions in state courts. ${ }^{35}$ As a result, it is quite possible that litigants and courts will more frequently face situations in which related class actions generate conflicts between state courts or between state and federal courts.

To reduce the likelihood that such conflicts will occur, and to extend the benefits of multidistrict transfer to cases brought in state court, some commentators have suggested that Congress grant the federal district

basis for a "companion" settlement of related claims in federal court. Morris \& See, The Hyatt Skywalks Litigation: The Plaintiffs" Perspective, 52 UMKC L. REv. 246, 270 (1984).

30. See 28 U.S.C. $\$ 1332$ (1982); cf. Manual for Complex Litigation $\$ 1.94$ (5th ed. 1982) (noting that statutory requirement of complete diversity often presents jurisdictional bar to air disaster claims in federal court, and results in parallel litigation in state and federal courts).

31. For example, in the Skywalks litigation, "[t]he overwhelming majority of victims lacked the diversity of citizenship necessary for federal court jurisdiction because they were either residents of Missouri or Kansas, and both Missouri and Kansas corporations were potential defendants." Morris \& See, supra note 29 , at 254 (footnote omitted).

32. 472 U.S. 797 (1985). For thorough analyses of the implications of the Shutts decision, see generally Kennedy, The Supreme Court Meets the Bride of Frankenstein: Phillips Petroleum Co. v. Shutts and the State Multistate Class Action, 34 U. KAN. L. REv. 255 (1985); Miller \& Crump, supra note 5.

33. 472 U.S. at 806-14; see World-Wide Volkswagen Corp. v. Woodson, 444 U.S. 286 (1980); International Shoe Co. v. Washington, 326 U.S. 310 (1945).

34. 472 U.S. at 811-12.

35. Comment, Choice of Law and the Multistate Class: Forum Interests in Matters Distant, 134 U. PA. L. REv. 913, 924 \& n.67 (1986) ("If [Shutts] had gone the other way, it would have largely closed the door to nationwide class actions in state courts by undercutting the ability of plaintiffs' attorneys to put together large classes.' ") (quoting Professor Lea Brilmayer of Yale Law School); see also Kennedy, supra note 32, at 301 (suggesting that Shutts' personal jurisdiction holding was in part intended to "keep small claim consumer cases out of the federal courts" by eliminating "constitutional barriers to the unrestricted maintenance of multistate class actions in state courts"). 
courts original and removal jurisdiction over multistate, multiparty cases. $^{38}$ Although such an expansion of federal jurisdiction could promote efficient and consistent adjudication, it could nonetheless produce the undesirable effect of "federalizing" virtually all multistate litigation. ${ }^{37}$ State courts can sometimes provide more appropriate and attractive forums for multistate cases than federal courts. For example, a majority of states "now offer class action procedures that, in terms of efficiency and convenience for the class, may equal or excel those . . . available in federal court."38 Moreover, litigation in a state forum is particularly desirable in lawsuits, such as tort cases, that concern fields of law with which state courts are most familiar. ${ }^{30}$

Litigation in a state court provides additional advantages when the court will be applying its own law. Litigation in a court of the jurisdiction whose law will be applied promotes fairness by eliminating the possibility that a federal court or a court of another state will misapply or misinterpret the controlling law; $;^{40}$ a plaintiff should not, for example, be left with

36. See, e.g., American Law Institute, Study of the Division of JuRisdiction BetweEn STATE AND FEDERAL CourTs 67-76, 375-410 (1969) [hereinafter ALI STudY]; Kamp, The Shrinking Forum: The Supreme Court's Limitation of Jurisdiction-An Argument for a Federal Forum in Multi-Party, Multi-State Litigation, 21 WM. \& MARY L. REv. 161, 182-88 (1979) (endorsing proposal of American Law Institute); Rowe \& Sibley, Beyond Diversity: Federal Multiparty, Multiforum Jurisdiction, 135 U. PA. L. REv. 7 (1986).

37. Cf. Miller \& Crump, supra note 5, at 76 ("[a]ny expansion of federal jurisdiction . . . should be carefully limited, so that it does not result in the federalizing of all class action practice").

38. Note, Multistate Plaintiff Class Actions: Jurisdiction and Certification, 92 Harv. L. Rev. 718, 718-19 \& nn.7-9; see also Comment, supra note 35, at 924 \& n.66. For example, some states have rejected the strict individual notice requirement of FED. R. CIv. P. 23(c)(2). Compare Cartt v. Superior Court, 50 Cal. App. 3d 960, 124 Cal. Rptr. 376 (1975) (trial court erred in requiring individual notice by mail in consumer class action) and Hoover v. May Dep't Stores Co., 62 Ill. App. 3d 106, 120, 378 N.E.2d 762, 774 (1978) ("not error to render a judgment without prior notice to the absent [class] members") with Eisen v. Carlisle \& Jacquelin, 417 U.S. 156 (1974) (individual notice must be provided to all reasonably identifiable members of federal class action). See generally $3 \mathrm{H}$. Newberg, Newberg on Cl.Ass Actions $\S 13.20$ (2d ed. 1985) (comparing federal and state approaches to notice in class actions).

In addition, some states have allowed cy-pres or "fluid recovery" distributions of damages, by which funds are distributed to a class of present or future class members who possess characteristics similar to those of the individuals actually victimized. See, e.g., Daar v. Yellow Cab Co., 67 Cal. 2d 695, 433 P.2d 732, 63 Cal. Rptr. 724 (1967); N.D.R. Grv. P. 23(o)(3)(E) (Uniform Class Action Rule) (permitting courts to distribute unclaimed funds to states in which class members reside); N.J.R. CIV. P. 4:32-2(c). In contrast, a number of federal courts have rejected fluid recovery. See, e.g., Abrams v. Interco, Inc., 719 F.2d 23, 31 (2d Cir. 1983) (Friendly, J.); In re Hotel Tel. Charges, 500 F.2d 86, 89-90 (9th Cir. 1974).

Finally, the amount-in-controversy requirement for federal diversity jurisdiction may bar some class actions from federal court. See Zahn v. International Paper Co., 414 U.S. 291 (1973) (each individual claim in federal diversity class action must meet jurisdictional amount-in-controversy requirement).

39. See Gulf Offshore Co. v. Mobil Oil Corp., 453 U.S. 473, 483-84 (1981) ("[s]tate judges have greater expertise" in handling personal injury claims governed by "rules . . . borrowed from state law"); Sheran \& Isaacman, State Cases Belong in State Courts, 12 CReIGHron L. Rev. 1, 61 \& n.306 (1978) (familiarity of state courts with issues commonly presented in diversity cases supports elimination of diversity jurisdiction).

40. See Thomas, The Erosion of Erie in the Federal Courts: Is State Law Losing Ground?, 1977 B.Y.U. L. REv. 1 (study of appellate opinions demonstrates tendency of federal courts to decide diver- 
the suspicion that he might have recovered but for one court's error in guessing at how another would have ruled. In addition, efficiency is fostered because the courts that are best able to determine a particular state's law quickly and efficiently are the courts of that state. In a few cases, litigation in a state court applying its own law obviates the need to engage in the expensive and time-consuming process of certifying legal questions from a court of another jurisdiction to the highest court of the state providing the governing law. ${ }^{41}$ Finally, litigation in the courts of the state

sity cases without resorting to state law); see also Texaco, Inc. v. Pennzoil Co., 626 F. Supp. 250, 254-56 (S.D.N.Y.) (state trial court in Texas incorrectly applied New York law on compensatory and punitive damages in entering $\$ 11.12$ billion judgment for tortious interference with contractual relations), affd in part and rev'd in part on other grounds, 784 F.2d 1133 (2d Cir.), rev'd on other grounds, No. 85-1798 (U.S. Apr. 6, 1987) (LEXIS, Genfed library, U.S. file).

The danger of error is perhaps greatest in cases of first impression. For example, in Gold v. JohnsManville Sales Corp., 553 F. Supp. 482 (D.N.J. 1982), the court predicted that, under New Jersey law, punitive damages were unavailable in an action based upon a theory of strict liability. Subsequently, however, a New Jersey court rejected this view, deeming it both "unpersuasive" and "erroneous." Fischer v. Johns-Manville Corp., 193 N.J. Super. 113, 123-24, 472 A.2d 577, 583 (App. Div. 1984). Fischer was later followed by a federal court in Gogol v. Johns-Manville Sales Corp., 595 F. Supp. 971 (D.N.J. 1984).

41. Even Chief Justice Rehnquist, an ardent advocate of deference to state courts, has cautioned against excessive use of certification procedures by federal courts, and has noted that "[w]hile certification may engender less delay and create fewer additional expenses for litigants than would abstention, it [nonetheless] entails more delay and expense than would an ordinary decision of the state question on the merits by the federal court." Lehman Bros. v. Schein, 416 U.S. 386, 394 (1974) (concurring opinion). Indeed, one writer has calculated that "it has taken an average of fifteen months from federal certification to federal application of the state response." Shapiro, Federal Diversity Jurisdiction: A Survey and a Proposal, 91 Harv. L. Rev. 317, 326-27 \& n.52 (1977) (relying on data in Note, Civil Procedure-Scope of Certification in Diversity Jurisdiction, 29 RUTGERs L. REV. 1155 (1976)). Another study, however, puts this figure at 9.56 months. C. SERon, Certifring Questions of State Law: Experience of Federal Judges 16 (1983) (Table 4).

Although certification occurs only infrequently, a state supreme court's response to certified questions can be of great importance. It can be crucial to the resolution of many cases in addition to the one certified. A sorry example of a state court abdicating its responsibility to answer certified questions is provided by Jackson v. Johns-Manville Sales Corp., 727 F.2d 506 (5th Cir.), reinstated in part and superseded in part on reh'g en banc, 750 F.2d 1314 (5th Cir.), questions certified, 757 F.2d 614 (5th Cir. 1984), certification declined, 469 So. 2d 99 (Miss. 1985), on reh'g en banc, 781 F.2d 394 (5th Cir.), cert. denied, 106 S. Ct. 3339 (1986). In Jackson, "an appeal of the first "asbestos case' tried in Mississippi," 757 F.2d at 616, the Fifth Circuit certified controlling questions of tort law to the Supreme Court of Mississippi, "which alone [could] furnish . . . an authoritative state-law decision on issues involved in hundreds of cases pending in the federal district courts." 750 F.2d at 1329 (Rubin, J., concurring). The Supreme Court of Mississippi, without explanation, chose not to address the certified issues, 469 So. $2 \mathrm{~d}$ at 99 , and left the Fifth Circuit to divine Mississippi law by its own devices.

Interstate certification-from a court of one state to a court of another-is theoretically possible, yet "no case has ever been certified from one state court to another." Reply Brief of Appellant Texaco, Inc. at 119, Texaco, Inc. v. Pennzoil Co., No. 01-86-0216-CV (Tex. Ct. App. Feb. 12, 1987). Nonetheless, a number of states have adopted interstate certification procedures. See $17 \mathrm{C}$. WRIGHT, A. Miller \& E. Cooper, Federal Practice and Procedure $\S 4248$ (1978). In its appeal of the widely publicized $\$ 11.12$ billion tortious interference judgment entered against it, Texaco urged an intermediate appellate court in Texas to request that the Supreme Court of Texas certify controlling issues of New York law to the Court of Appeals of New York. Brief of Appellant Texaco, Inc. at 116, Texaco, Inc. v. Pennzoil Co., No. 01-86-0216-CV (Tex. Ct. App. Feb. 12, 1987). Texaco's request was denied. Texaco, Inc. v. Pennzoil Co., No. 01-86-0216-CV, slip op. at 161 (Tex. Ct. App. Feb. $12,1987)$. 
providing the controlling law reduces uncertainty about legal standards for future behavior by providing a direct opportunity for definitive appellate review.

Furthermore, an expansion of federal jurisdiction to embrace all multistate, multiparty cases involving state law would aggravate the already overburdened condition of the federal courts, a condition that for many years has led prominent jurists to call for the curtailment or elimination of diversity jurisdiction. ${ }^{42}$ In addition, the introduction of more questions of state law into federal court could only serve to distract the federal judiciary from the achievement of its central purpose-the interpretation and enforcement of federal law. ${ }^{43}$ To maintain a proper balance of authority between the federal and state judiciaries, and to make beneficial use of state judicial procedures and resources, any attempt to expand the availability of consolidated adjudication should seek to strengthen the role of state courts in resolving multistate disputes. Ideally, provisions should be made to permit and encourage consolidation in state courts.

\section{Consolidation in State Courts: A Proposal}

The need to promote consolidation of multistate litigation must be reconciled with the need to preserve the authority of state courts. Striking this balance is indeed difficult, and requires both centralized, federal decisionmaking (to promote consolidation) and federal deference (to allow adjudication in state courts). Congress should provide for consolidated adjudication of multistate cases in state courts by amending 28 U.S.C. $\S$ 1407 to allow the Judicial Panel on Multidistrict Litigation to transfer cases both to and from state courts in much the same manner that the Panel today transfers cases to and from federal courts. ${ }^{44}$ To maximize the

42. See, e.g., H. Friendly, Federal Jurisdiction: A General View 141 (1973); Bork, Dealing with the Overload in Article III Courts, 70 F.R.D. 231, 236-37 (1976); Frankfurter, Distribution of Judicial Power Between United States and State Courts, 13 CoRnell L. Q. 499 (1928); Friendly, The Historic Basis of Diversity Jurisdiction, 41 HARv. L. REv. 483 (1928); Hazard, Interstate Venue, 74 Nw. U.L. REv. 711, 713 (1979); Letter from Chief Justice Warren E. Burger to Senator Roman L. Hruska (May 29, 1975), reprinted in Commission on the Revision of the Federal Court Appellate System, Structure and Internal Procedures: Recommendations for Change, 67 F.R.D. 195,398 (1975).

43. See, e.g., Amar, A Neo-Federalist View of Article III: Separating the Two Tiers of Federal Jurisdiction, 65 B.U.L. REv. 205, 269 (1985); Rowe, Abolishing Diversity Jurisdiction: Positive Side Effects and Potential for Further Reforms, 92 HARv. L. REv. 963, 1011 (1979).

Although the technical competence of the federal courts might seem generally to support expanded federal jurisdiction, it must be recognized that this competence stems, in part, from the "relatively small" size of the federal bench. Neuborne, The Myth of Parity, 90 HARv. L. REv. 1105, 1121 (1977). Indeed, some judges have suggested that overexpansion of the federal judiciary would lead to a decline in its quality, and that its special skills should be reserved for the articulation of federal law. See, e.g., Lumbermen's Mut. Casualty Co. v. Elbert, 348 U.S. 48, 59 (1954) (Frankfurter, J., concurring); H. FRIENDLY, supra note 42, at 29-30; Frankfurter, supra note 42, at 515-16.

44. Professor Elinor Schroeder has suggested that a system of interstate transfer patterned after 
benefits of consolidation, Congress should expressly grant the Judicial Panel the authority to transfer cases to state or federal courts for trial as well as for pretrial proceedings. ${ }^{4}$ Given this authority, the Panel could order the transfer of cases initially filed in state courts to a single federal district court for consolidation with federal actions. ${ }^{46}$ Under appropriate circumstances, the Panel would have the additional option to transfer lawsuits, regardless of origin, to a single state court for consolidated adjudication. Consolidation in state court would, as noted above, be especially desirable in cases that require the transferee state court to interpret and apply local substantive law.

$\S 1407$ should be created by interstate compact. Schroeder, Relitigation of Common Issues: The Failure of Nonparty Preclusion and an Alternative Proposal, 67 IowA L. REv. 917, 963-79 (1982). Under Schroeder's proposal, civil actions presenting common issues of fact pending in more than one state could be transferred to a single state court for consolidated pretrial proceedings. The panel authorized to order such transfers would consist of a judge from each of the states that join the compact. Id. at 965 .

This proposal, however, faces several drawbacks. First, its effectiveness could be severely limited by the refusal of even a small number of states to join the compact. Second, the proposal contemplates that transferred cases would "always" be remanded to their original courts for trial, id. at 979, and thus would not capitalize on the potential benefits of consolidation for trial. See supra notes 27-28 and accompanying text. Third, Schroeder's multistate panel would be hindered by her proposed requirement that it secure the consent of the state to which cases would be transferred before it could order transfer. See id. at 966 . Fourth, under Schroeder's proposal, no device would exist for the consolidation of related actions filed in both state and federal court.

45. According to the House report on $\S 1407$, Congress refused to authorize consolidation for trial for four reasons. First, in the electrical equipment antitrust cases, the federal courts had experience only in arranging coordinated pretrial proceedings, and Congress "consider[ed] it desirable to keep [the] legislative proposal within the confines of [this] experience." H.R. REP. No. 1130, supra note 20 , at 4 . Second, the statute's drafters felt that "it may be impracticable to have all cases in mass litigation tried in one district." Id. Third, the House report noted that parties and witnesses generally preferred trial in the original district. Id. Fourth, the legislators believed that there would be "a need for local discovery proceedings to supplement coordinated discovery proceedings," making remand "desirable." Id.

As one commentator has observed, "the importance of these considerations was probably overestimated by the drafters." Note, supra note 15, at 1036. Experience has shown that "trial of complex issues in one court is frequently practical and efficient." Id.; see also Weigel, supra note 15, at 581-85. Moreover, local discovery has often been unnecessary because multidistrict cases have tended to settle either during pretrial or after trial of common issues. Note, supra note 15, at 1037. Finally, because 28 U.S.C. $\$ 1404$ (a) has been used to consolidate litigation for trial, see supra note 23 , plaintiffs' forum choice has in fact not received the protection anticipated by the drafters of $\S 1407$, and thus would not be greatly affected by an amendment of $\S 1407$ to allow consolidation for trial. Such an amendment would allow the Judicial Panel and transferee courts efficiently to perform in one step what in effect is already done in two.

46. Theoretically, consolidation in federal courts of cases initially filed in state courts may occur today in a limited number of cases for which federal removal jurisdiction already exists. The proposal set forth in this Note, however, would greatly expand the potential for such consolidated adjudication in federal court by creating general federal jurisdiction over multistate, multiparty cases that may be exercised by federal courts at the discretion of the Judicial Panel. See infra notes 68-106 and accompanying text. For the Panel to enforce its orders, Congress must "expressly authorize[]" the Panel to "grant . . . injunction[s] to stay proceedings in [s]tate court[s]." Anti-Injunction Act, 28 U.S.C. $\S$ 2283 (1982). 


\section{Multistate Litigation in State Courts}

\section{A. Standards for Removal}

In setting standards for the removal of cases from state courts for transfer elsewhere, Congress should instruct the Judicial Panel to weigh the same factors that the Panel considers today in transferring cases among the federal district courts. These factors include the extent to which the various lawsuits share factual ${ }^{47}$ and legal ${ }^{48}$ questions; the location of witnesses and parties; ${ }^{49}$ the extent to which any of the actions have reached advanced stages of pretrial, ${ }^{, 0}$ the potential for detriment, financial or otherwise, to a party as a result of transfer; ${ }^{.51}$ and the danger that inconsistent rulings may result if transfer and consolidation are not ordered. ${ }^{\mathbf{5 2}}$

\section{B. Consolidation and the Selection of the Transferee Forum}

Unlike the removal of litigation from state courts, which occurs thousands of times each year under ordinary removal statutes, ${ }^{83}$ the transfer to state courts of litigation originating in federal courts or in the courts of another state could generate friction and conflict between the federal Judicial Panel and transferee state courts. Consolidated multistate litigation can place great burdens on transferee courts, despite the overall savings in time and energy that consolidation may bring. ${ }^{54}$ Moreover, state

47. See, e.g., In re Washington Pub. Power Supply Sys. Sec. Litig., 568 F. Supp. 1250, 1251 (J.P.M.D.L. 1983) (transfer of "thirteen actions involv[ing] common questions of fact"); 28 U.S.C. § 1407 (a) (1982) (authorizing transfer of "civil actions involving one or more common issues of fact").

48. Although the existence of common legal questions is relevant to the decision on whether or not to order transfer, see, e.g., In re Mutual Fund Sales Antitrust Litig., 361 F. Supp. 638, 640 (J.P.M.D.L. 1973) (question as to exemption from antitrust laws "common to all actions in this litigation"), common legal questions alone will not satisfy the requirements of $\$ 1407$. See, e.g., In re Airline "Age of Employee" Employment Practices Litig., 483 F. Supp. 814, 817 (J.P.M.D.L. 1980) (transfer held inappropriate because "common questions . . . will be mainly legal").

49. See, e.g., In re Union Carbide Corp. Gas Plant Disaster at Bhopal, India in Dec., 1984, 601 F. Supp. 1035, 1036 (J.P.M.D.L. 1985) (noting proximity of defendant's corporate headquarters, where "relevant witnesses and documents may be located," to transferee district).

50. See, e.g., In re Upjohn Co. Antibiotic "Cleocin" Prods. Liab. Litig., 450 F. Supp. 1168, 1170 (J.P.M.D.L. 1978) (order transferring twelve related actions against common defendant to single district, but excluding lawsuits for which discovery had been completed).

51. Although transfer must serve the "convenience of parties and witnesses," 28 U.S.C. § 1407(a) (1982), objections to transfer on grounds of inconvenience are usually overruled by the Panel, which invariably asserts that inconveniences may be outweighed and overcome by efficient management of the litigation. 15 WRIGHT \& MILLER, supra note 15, \& 3863; see, e.g., In re Air Crash Disaster near Chicago, Ill., on May 25, 1979, 476 F. Supp. 445, 447-48 (J.P.M.D.L. 1979).

52. See, e.g., In re "Agent Orange" Prod. Liab. Litig., 597 F. Supp. 740, 752 (E.D.N.Y. 1984); In re LTV Corp. Sec. Litig., 470 F. Supp. 859, 862 (J.P.M.D.L. 1979).

53. From June 30,1984 to June 30,1985 , for example, 17,439 cases were removed from state courts to federal district courts, accounting for $6.4 \%$ of the total number of civil cases filed in the federal district courts that year. ADMIN. OfFICE OF THE U.S. CoURTS, AN ANALYSIS OF THE WORKload of the Federal Courts for the Twelve Month Period Ended June 30, 1985, reprinted in ANNUAL Report of the DiRector of THE AdMINISTRATIVe OfFICE OF THE UNITED States Courts 1985, at 136 (1985) [hereinafter ANNUAL RePORT 1985].

54. For example, in In re Multidistrict Civil Antitrust Actions Involving Antibiotic Drugs, $320 \mathrm{~F}$. Supp. 586, 588 (J.P.M.D.L. 1970), the Judicial Panel, "recogniz[ing] that this litigation has become 
courts may vary tremendously in their ability to handle complex cases. ${ }^{85}$ Because consolidated multistate litigation might "overload" some state courts, Congress should carefully define and circumscribe the Judicial Panel's authority to order the transfer of litigation to state courts.

Specifically, transfer to a state court should only occur when it is clearly demonstrated that litigation before the state tribunal would be as fair and efficient as litigation in federal court. The Panel should, for example, be required to give great weight to the state court's caseload. ${ }^{56}$ The Panel should also be required to examine carefully the ability, as demonstrated by past experience ${ }^{57}$ or by the existence or absence of efficient state procedural rules, ${ }^{\mathrm{B}}$ of the state court to handle the litigation.

The Panel should also carefully determine the extent to which state rules of venue, and legislative and constitutional limitations on the exercise of personal jurisdiction by potential transferee state courts, might preclude the consolidation of all related litigation in one state court. The experience of the Panel in ordering transfer among federal trial courts, however, suggests that these limitations will not unduly restrict the power of the Panel to consolidate litigation in state courts. The Panel has shown a strong tendency to transfer litigation under section 1407 to federal districts in which venue and personal jurisdiction requirements are met, so that the transferee district, in turn, may properly use statutory provisions on change of venue to transfer the litigation to itself for trial. ${ }^{58}$ Because the applicability of rules of venue and personal jurisdiction have not pre-

too large and too complex to be processed by a single judge," temporarily assigned a second judge from a distant district court to the transferee district in order to handle some of the cases in the litigation.

55. Cf. Rowe, supra note 43, at $983-84$ (noting that although some state court systems lag behind others in matching "interstate and international capability" of federal courts, state courts "could approach" federal court competence through enactment of appropriate legislation).

56. The Judicial Panel currently considers the relative conditions of court dockets in selecting federal transferee courts under $\$ 1407$. See, e.g., In re Corn Derivatives Antitrust Litig., 486 F. Supp. 929, 932 (J.P.M.D.L. 1980) (selecting district having fewer pending class actions and "drastically fewer multi-district litigations than . . . other suggested transferee districts").

57. "[T]he panel has demonstrated a propensity for assigning consolidated cases to judges who have some experience with the general problems inherent in complex and multidistrict litigation land has] on a number of occasions . . . assigned cases to one of its own members." 15 WRIGHT \& Miller, supra note $15, \S 3864$, at 572 . The Panel could similarly rely upon the expertise of state courts. For example, a number of state courts have developed extensive experience with asbestosrelated lawsuits. See Parrish, supra note 29 , at 6.

58. See supra notes 38,55 and accompanying text.

59. See 15 WRIGHT \& MilleR, supra note $15, \S 3864$, at 560; In re Multidistrict Civil Actions Involving the Air Crash Disaster near Hanover, N.H., on Oct. 25, 1968, 314 F. Supp. 62, 63 (J.P.M.D.L. 1970) (ordering transfer to "the only district in which all defendants can be sued by any plaintiff"). Section 1404(a) provides that "a district court may transfer any civil action to any other district . . . where it might have been brought." 28 U.S.C. $\$ 1404$ (a) (1982) (emphasis added). Accordingly, $\$ 1404$ (a) transfer is proper if, "at the time of the commencement of the action[,] . . . venue [was] proper in the transferee district and the transferee court . . had power to command jurisdiction over all of the defendants." Shutte v. Armco Steel Corp., 431 F.2d 22, 24 (3d Cir. 1970). 
vented the Judicial Panel from facilitating transfer for trial under existing federal procedures, ${ }^{60}$ it is unlikely that such rules would significantly hinder consolidation in state court. ${ }^{\mathbf{B}}$

In any event, if complete consolidation in state court is not possible, the Panel may instead order the transfer of all the litigation to an appropriate federal district court. Alternatively, the Panel could transfer as many of the cases as possible to the state court and send the remainder to the federal district court in the district in which the state court sits. ${ }^{62}$ Such a transfer in tandem would allow the state and federal judges informally to coordinate the litigation through, for example, joint pretrial conferences, which state and federal judges have found to be extremely worthwhile. ${ }^{69}$

Finally, and perhaps most importantly, the Judicial Panel should be permitted to order the transfer of multistate litigation to state courts only in those cases in which liability after transfer is expected to depend largely, if not wholly, upon the law of the transferee jurisdiction. ${ }^{64}$ Such a

60. See 15 WRIGHT \& MiLleg, supra note $15, \S 3864$, at 560 n.14 (listing examples).

61. The difficulties posed by state venue requirements would vary from state to state. Nevertheless, to the extent that states rely on commonly used venue criteria such as those permitting suits "[w]here the 'cause of action' 'arose" " or "[w]here the defendant has a place of business or may be 'found," D. Louisell, G. Hazard \& C. Tait, Cases and Materials on Pleading and ProCEDURE 460 (5th ed. 1983), consolidation in one court will often be possible. Cf. 28 U.S.C. $\$ 1391$ (a) (1982) (diversity actions may be brought in district where "all defendants reside, or in which the claim arose"). In addition, several states have established internal mechanisms for the transfer and consolidation of related cases filed in different state courts. W. TuRLEY, supra note $9, \S 12.04$, at 433 \& nn.72-80; see, e.g., CAl. Giv. Proc. Code $\$ \S 404,404.1-.8$ (West 1973 \& Supp. 1986) (authorizing state Judicial Council to order interdistrict transfer and "coordinated" trials before a single judge); MASS. GEN. LAWS ANN. ch. 223, $\$ \S 2 A, 2 B$ (West 1985) (authorizing, inter alia, interdistrict transfer and consolidated trial of actions "arising out of or connected with the same accident, event, or transaction"); N.Y. Civ. PrAc. L. \& R. $\S 602$ (b) (Consol. 1978) (authorizing supreme court to "remove to itself an action pending in another court and consolidate it or have it tried together with that [sic] in the supreme court'). The creation of a system of interstate transfer might encourage other states to establish mechanisms for intrastate transfer and consolidation.

62. Cf. In re Oil Spill by the "Amoco Cadiz", 471 F. Supp. 473, 479 (J.P.M.D.L. 1979) (selection of transferee district guided by possibility that "related actions . . . in . . . Illinois state courts can be coordinated with the federal proceedings there").

63. See Manual for Complex Litigation, Second § 31.31 (1985). Although the Manual for Complex Litigation, Second suggests that "consideration . . . be given to a joint trial, at which separate state and federal juries would sit ... and hear common evidence," id. $\$ 31.31$, at 261 n.53 (emphasis added), such a suggestion was rejected in the Skywalks litigation, see supra note 29, by the federal district court, which deemed the idea "wholly unworkable, unmanageable, and unsatisfactory." Student Project, supra note 29, at 170 \& n.146. Nevertheless, the two courts cooperated extensively to facilitate "a massive [joint] discovery effort." Morris \& See, supra note 29, at 254.

64. Federal transferee courts under $\S 1407$ are required to apply the choice of law rule that would have been applied by the transferor court. See, e.g., In re "Agent Orange" Prod. Liab. Litig., 580 F. Supp. 690, 692-93, 695 (E.D.N.Y. 1984); cf. Van Dusen v. Barrack, 376 U.S. 612 (1964) (transferee court under 28 U.S.C. $§ 1404(a)$ must follow law that transferor court would have applied).

This Note assumes, however, that a transferee state court under an amended § 1407 would remain free to apply its own choice of law rule, and that transfer to the state court will be favored when this choice of law rule dictates that the substantive law of the forum will dominate the litigation after transfer. To the extent that the choice of law in the transferee court differs from the law that would be applied in the transferor court, a change in the outcome of a particular case may be compelled as 
rule would help to prevent the overburdening of state trial courts by limiting transfer to the cases most appropriately handled by those courts. ${ }^{65}$ Conflict between state courts and the Judicial Panel would be minimized by this rule because state courts would not have cases based on federal law or the law of another state "forced" upon them by the Panel. ${ }^{68}$ Indeed, an option to consolidate in state court would promote cooperation between the federal and state judiciaries ${ }^{67}$ by giving state courts greater opportunity to refine and apply their own law.

\section{Gonstitutional Issues}

Although this Note's proposal to extend the authority of the Judicial Panel on Multidistrict Litigation might seem to defy traditional notions of American constitutional federalism, the constitutionality of the proposal can be wholly supported by existing precedent. Indeed, the proposal serves to promote federalistic values by giving state courts an opportunity to remain active in a field that could be wholly preempted by federal law.

\section{A. The Scope of Article III Subject-Matter Jurisdiction}

In order for the Judicial Panel to remove multistate, multiparty litigation from state courts, the statutory limits of federal court subject-matter jurisdiction must be expanded to encompass these cases. Legislation broadening the statutory limits of federal jurisdiction has been proposed and considered in the past by scholars, ${ }^{68}$ the Justice Department, ${ }^{68}$ and

the result of transfer. Considerations of efficiency and fairness may nevertheless override any hesitancy of the Panel to order transfer that might exist because of any such potential effect on outcome. Under the doctrine of forum non conveniens, for example, similar concerns dictate that "[t]he possibility of a change in substantive law should ordinarily not be given conclusive or even substantial weight . . . ." Piper Aircraft Co. v. Reyno, 454 U.S. 235, 247 (1981); see also In re Union Carbide Corp. Gas Plant Disaster at Bhopal, India in Dec., 1984, 809 F.2d 195 (2d Cir. 1987) (allowing forum non conveniens dismissal in favor of litigation before Indian court).

65. See supra notes $39-43$ and accompanying text.

66. Nevertheless, a state tribunal is bound by the supremacy clause, U.S. CoNST. art. VI, to entertain most federal causes of action, see infra notes 113-29 and accompanying text, and is prohibited by the due process clause of the Fourteenth Amendment, id. amend. XIV, $\S 1$, and by the full faith and credit clause, id. art. IV, $\S 1$, from arbitrarily applying the law of the forum state to a controversy before it. See Phillips Petroleum Co. v. Shutts, 472 U.S. 797, 818 (1985) ("[F]or a State's substantive law to be selected in a constitutionally permissible manner, that State must have a significant contact or significant aggregation of contacts [with the litigation], creating state interests, such that choice of its law is neither arbitrary nor fundamentally unfair.") (quoting Allstate Ins. Co. v. Hague, 449 U.S. 302, 312-13 (1981)).

67. Cf. Lehman Bros. v. Schein, 416 U.S. 386, 391 (1974) (certification procedures "help[] build a cooperative judicial federalism").

68. See sources cited supra note 36.

69. See Letter from Assistant Attorney General Daniel J. Meador to Representative Robert W. Kastenmeier (June 25, 1979) (Appendix A), reprinted in Diversity of Citizenship Jurisdiction/Magistrates Reform-1979: Hearings Before the Subcomm. on Courts, Civil Liberties, and the Administration of Justice of the House Comm. on the Judiciary, 96th Cong., 1st Sess. 158-62 (1979) [hercinafter Diversity Hearings]. 
members of Congress, ${ }^{70}$ and could be based either upon diversity of citizenship or upon the power of Congress to regulate interstate and foreign commerce. $^{71}$

\section{Diversity Jurisdiction}

Specifically, article III of the Constitution extends the "judicial Power [of the United States] . . . to Controversies . . . between Citizens of different States . . . and between a State, or the Citizens thereof, and foreign States, Citizens or Subjects."72 Although the statute conferring diversity jurisdiction ${ }^{73}$ has long been held to require "complete diversity,"74 meaning that "where co-citizens appeared on both sides of a dispute, jurisdiction was lost," article III as requiring only "minimal diversity."78 In State Farm Fire $\mathbb{E}$ Casualty Co. v. Tashire, ${ }^{77}$ the Court held that article III "poses no obstacle to the legislative extension of federal jurisdiction, founded on diversity, so long as any two adverse parties are not co-citizens." ${ }^{.78}$ Congress could thus extend federal jurisdiction over a large number of multistate cases by providing for federal subject-matter jurisdiction in cases of minimal diversity in which a threshold number of claimants alleges damages exceeding certain monetary amounts. ${ }^{79}$

\section{2. "Federal Question" Jurisdiction}

Alternatively, the federal courts could be given "federal question" jurisdiction over multistate, multiparty cases. Article III extends federal judicial power "to all Cases, in Law and Equity, arising under . . . the Laws of the United States." ${ }^{\text {o }}$ The words "arising under," and the scope of fed-

70. See, e.g., H.R. 4315, 99th Cong., 2d Sess., 132 Cong. REc. H827 (1986) (proposal of Representative Robert W. Kastenmeier); H.R. 3690, 98th Cong., 1st Sess., 129 CoNG. Rec. 5918 (1983) (same); cf. Tydings, supra note 4, at 310-11 (proposal of Senator Joseph D. Tydings to establish exclusive federal jurisdiction over suits arising from aviation disasters).

71. The ALI based its proposal solely on the diversity clause, U.S. CoNST. art. III, § 2; see ALI STUDY, supra note 36, at 426-36 (Supporting Memorandum A), as does Professor Rowe, see Rowe \& Sibley, supra note 36 . One proposal to create federal jurisdiction over consumer class actions, $S$. 1980, 91 st Cong., 1st Sess., 115 CoNG. REc. 10,460-61 (1969), relied on a theory of protective jurisdiction. See Note, Protective Jurisdiction and Adoption as Alternative Techniques for Conferring Jurisdiction on Federal Courts in Consumer Class Actions, 69 Mich. L. REv. 710, 724-31 (1971).

72. U. S. Consr. art. III, $\S 2$.

73. 28 U.S.C. $\S 1332$ (1982).

74. See, e.g., Strawbridge v. Curtiss, 7 U.S. (3 Cranch) 267 (1806) (Marshall, C.J.).

75. State Farm Fire \& Casualty Co. v. Tashire, 386 U.S. 523, 530-31 (1967).

76. Id.

77. 386 U.S. 523 (1967).

78. Id. at 531 .

79. See Rowe \& Sibley, supra note 36, at 49-54 (proposed 28 U.S.C. § 1367); see also ALI STUDY, supra note 36 , at 426 .

80. U.S. Const. art. III, § 2. 
eral question jurisdiction, have traditionally been interpreted very broadly. Indeed, so potentially expansive is federal question jurisdiction that the Court has not yet ruled out the validity of theories of "protective jurisdiction." 81 These theories, in various forms, assert that the applicable federal law under which a case "arises" could be a purely jurisdictional statute providing a federal forum for the application of state law in a field in which Congress could (but does not) enact preemptive substantive legislation. $^{82}$ The Supreme Court's approval of laws granting bankruptcy trustees the right to sue on state claims in federal district courts $^{83}$ suggests that the federal courts could, given the proper statutory authority, assert federal question jurisdiction over multistate, multiparty cases based on the commerce power and an assertion of protective jurisdiction. ${ }^{84}$

Federal jurisdiction over multistate cases need not, however, be premised on protective jurisdiction, the constitutionality of which has long stimulated sharp disagreement among both judges and scholars. ${ }^{85}$ Current interpretation of the "arising under" clause amply supports the validity of the proposed legislation. Under the Supreme Court's most recent pronouncement on the issue, Verlinden B.V. v. Central Bank of Nigeria, ${ }^{86}$ federal question jurisdiction may constitutionally be asserted over any lawsuit involving a federal law that does more than regulate access to the federal courts. ${ }^{87}$ Because an amended section 1407 would require the Ju-

81. See, e.g., Verlinden B.V. v. Central Bank of Nig., 461 U.S. 480, 491 n.17 (1983) (declining to address constitutionality of "protective jurisdiction").

82. See Note, The Theory of Protective Jurisdiction, 57 N.Y.U. L. REv. 933, 936 (1982) (describing protective jurisdiction as that exercised "over cases (1) in federal court (2) between nondiverse parties (3) governed by nonfederal rules of decision") (citations omitted).

The concept of protective jurisdiction was originally introduced by Professors Paul Mishkin and Herbert Wechsler, see Mishkin, The Federal "Question" in the District Courts, 53 Colum. L. Rev. 157, 184-96 (1953); Wechsler, Federal Jurisdiction and the Revision of the Judicial Code, 13 LAW \& Contemp. Probs. 216, 224-25 (1948), and received the implicit endorsement of Justices Jackson, Black, and Burton in National Mutual Insurance Co. v. Tidewater Transfer Co., 337 U.S. 582, 599 (1949), as well as the explicit approval of Justices Burton and Harlan in Textile Workers Union v. Lincoln Mills, 353 U.S. 448, 460 (1957) (Burton, J., concurring).

83. See, e.g., Schumacher v. Beeler, 293 U.S. 367 (1934); Sherman v. Bingham, 21 F. Cas. 1270, 1272 (C.C.D. Mass. 1872) (No. 12,762).

84. See Mishkin, supra note 82, at 189-90 \& n.141, 193-94; Note, supra note 82, at 974-83; $c f$. Tidewater Transfer, 337 U.S. at 599 (Jackson, J., announcing judgment of Court) ("The fact that the congressional power over bankruptcy granted by Art. I could open the court to the trustee does not mean that such suits arise under the laws of the United States; but it does mean that Art. I can supply a source of judicial power for their adjudication.").

85. Among the harshest critics of protective jurisdiction was Justice Frankfurter. See Lincoln Mills, 353 U.S. at 473-77 (Frankfurter, J., dissenting). Other critical views include ALI STUDY, supra note 36, at 483-84 (Appendix C); M. Redish, Federal JuRisdiction: Tensions in the Allocation of Judicial Power 62-63 (1980); Currie, The Federal Courts and the American Law Institute, 36 U. CHI. L. REv. 1, 14-15 (1968).

86. 461 U.S. 480 (1983).

87. See id. at 496 ("The [Foreign Sovereign Immunities] Act does not merely concern access to the federal courts."); The Supreme Court, 1982 Term, 97 HARv. L. REv. 70, 214 (1983) [hereinafter 1982 Term]. 
dicial Panel not only to assert jurisdiction, but also to apply federal standards governing the selection of transferee courts, federal question jurisdiction could constitutionally be asserted over the multistate cases that would be removed from state courts. ${ }^{88}$

Verlinden concerned the question of whether the Foreign Sovereign Immunities Act of $1976^{88}$ (FSIA) could constitutionally authorize a foreign plaintiff to sue a foreign state in federal court on a nonfederal cause of action. Specifically, the litigation arose from a contract for the purchase of cement between the Federal Republic of Nigeria and Verlinden B.V., a Dutch corporation with its principal offices in Amsterdam..$^{90}$ After the Central Bank of Nigeria, an instrumentality of the Federal Republic, unilaterally directed its banks to amend the letter of credit issued in connection with the contract, Verlinden brought suit in the United States District Court for the Southern District of New York, alleging that the Bank's actions constituted an anticipatory breach of the letter of credit. ${ }^{91}$

In support of its claim, Verlinden argued that subject-matter jurisdiction existed under the Foreign Sovereign Immunities Act, which governs assertions of sovereign immunity by foreign states, ${ }^{92}$ and which provides that " $[t]$ he district courts shall have original jurisdiction . . . of any nonjury civil action against a foreign state ... [that] is not entitled to immunity either under [the FSIA] or under any applicable international agreement." the Bank was entitled to sovereign immunity. ${ }^{94}$ The Second Circuit affirmed on different grounds, however, and without addressing the question of whether sovereign immunity existed under the statute, ${ }^{98}$ held that neither the diversity clause ${ }^{98}$ nor the "arising under" clause of article III was broad enough to authorize jurisdiction over an action brought by a foreign plaintiff against a foreign state when no federal rule of decision governed the claim. ${ }^{97}$

88. See infra notes $102-03$ and accompanying text.

89. Foreign Sovereign Immunities Act of 1976, 28 U.S.C. $\S \S 1330,1602-1611$ (1982).

90. 461 U.S. at 482 .

91. Id. at 483 .

92. See 28 U.S.C. $\S \S 1602-1611$ (1982).

93. 28 U.S.C. $\$ 1330$ (1982).

94. Verlinden B.V. v. Central Bank of Nig., 488 F. Supp. 1284 (S.D.N.Y. 1980).

95. The court noted only that 28 U.S.C $\$ 1330$ did not, on its face, limit the scope of jurisdiction over actions against foreign states only to those brought by American citizens. Verlinden B.V. v. Central Bank of Nig., 647 F.2d 320, 324 (2d Cir. 1981).

96. Although article III provides for subject-matter jurisdiction over suits "between a State, the Citizens thereof, and foreign States, Citizens, or Subjects," U.S. ConsT. art. III, § 2, it "nowhere mentions a case between two aliens." 647 F.2d at 325 .

97. 647 F.2d at 325-30. The Second Circuit noted that the parties had agreed that Verlinden's claim for the breach of the letter of credit was governed by either the Uniform Customs and Practice for Documentary Credits of the International Chamber of Commerce, or the law of New York. Id. at 326. 
The Supreme Court unanimously reversed, holding that "a suit against a foreign state under [the FSIA] necessarily raises questions of substantive federal law at the very outset" of the litigation, and "hence clearly "arises under' federal law, as that term is used in Art[icle] III." ${ }^{\prime 28}$ The Court distinguished language in prior cases suggesting that a jurisdictional statute could never constitute the federal law under which a case "arises," noting that "the statutes at issue in these . . . cases sought to do nothing more than grant jurisdiction over a particular class of cases." emphasized that the FSIA, in contrast, not only conferred jurisdiction, but also, by "comprehensively regulating the amenability of foreign nations to suit in the United States,"100 constituted an exercise of article I powers over foreign commerce and foreign affairs. ${ }^{101}$

Like the FSIA, the proposal set forth in this Note would require a federal court to apply "substantive federal law"-specifically, the standards for transfer and consolidation set forth by an amended section 1407 and by interpretive case law. Legislation expanding the authority of the Judicial Panel would act as far more than a jurisdictional grant; ${ }^{202}$ it would, like the FSIA, constitute an exercise of article I power through a scheme of regulation as "detailed" and "comprehensive[]"10s as the inquiry governing sovereign immunity. An amended section 1407, moreover, could not seriously be challenged on the ground that it exceeds the delegated powers of Congress under article I. It is well-settled law that Congress may regulate any activity, however local in nature, if it rationally finds that the activity affects interstate or foreign commerce in any discernible way. ${ }^{104}$ The extraordinary expense of multistate litigation today ${ }^{105}$ would amply justify a finding by Congress that such litigation af-

98. 461 U.S. at 493.

99. Id. at 496 .

100. Id. at 493 .

101. Id. at 496 .

102. In fact, an amended $\S 1407$ would be less "jurisdictional" in nature than the FSIA because it would require the application of legal standards that are unrelated to any jurisdictional inquiry; the Panel's jurisdiction over multistate litigation would not depend upon the Panel's choice of transferee forum. In contrast, the Court in Verlinden conceded not only that the issue of sovereign immunity was the only issue of federal law in the case, but thas the issues of subject-matter jurisdicion and sovereign immunity were inextricably linked; under the FSIA, subject-matter jurisdiction existed if and only if sovereign immunity were found not to exist. See 461 U.S. at 485 n.5, 489, 493-94. One analysis of Verlinden, while generally approving of the decision, notes that "[t]he characterization of sovereign immunity as a substantive issue is dubious enough to call into question the usefulness of the substance/jurisdiction distinction as a limiting principle." 1982 Term, supra note 87, at 213.

103. 461 U.S. at $493,494$.

104. See, e.g., Garcia v. San Antonio Metro. Transit Auth., 469 U.S. 528, 537 (1985); Hodel v. Virginia Surface Mining \& Reclamation Ass'n, 452 U.S. 264, 275-77 (1981); Perez v. United States, 402 U.S. 146 (1971); Katzenbach v. McClung, 379 U.S. 294 (1964); Wickard vं. Filburn, 317 U.S. 111 (1942); United States v. Darby, 312 U.S. 100 (1941).

105. See supra notes $2-3$ and accompanying text. 
fects interstate commerce. ${ }^{108}$ Federal legislation designed to curtail the waste resulting from duplicative litigation in state and federal courts would thus fall within the constitutional scope of the commerce power. Thus, under Verlinden, the application of an amended section 1407 would constitutionally suffice to support the exercise of federal question jurisdiction.

\section{B. The Tenth Amendment and Federal Structure}

The legislative proposal set forth in this Note would not violate any constitutional limitations that the Tenth Amendment or federal structure may impose upon the power of the national government. The Supreme Court has recently abandoned the short-lived doctrine of National League of Cities $v$. Usery, ${ }^{107}$ under which the Tenth Amendment had been interpreted as prohibiting Congress from exercising its power over commerce in a fashion that would "directly impair" a state's ability to "structure integral operations in areas of traditional governmental functions." ${ }^{108}$ In Garcia v. San Antonio Metropolitan Transit Authority, ${ }^{109}$ the Court overruled National League of Cities and held that Congress could constitutionally impose the requirements of the Fair Labor Standards Act upon state and local governments. Observing that the "principal and basic limit[s] on the federal commerce power . . . [are] the built-in restraints that our system provides through state participation in federal governmental action,"110 the Court rejected the "judicially created limitations on federal power" 111 adopted in National League of Cities. The Court concluded that "[a]ny substantive restraint on the exercise of Commerce Clause powers must find its justification in the procedural nature of this basic limitation, and . . . must be tailored to compensate for possible failings in the national political process."112 Should Garcia remain the law, ${ }^{113}$ any grant to the Judicial Panel of authority over state courts would not implicate this federalistic limitation on congressional power, be-

106. Similarly, President Reagan has called for the passage of a national products liability law that would be based upon findings that "the free flow of products in commerce has been increasingly burdened by product liability law" and that "the unacceptably high transactions costs of the product liability system ... is a burden on the consumer and American industry which can no longer be tolerated ...."S. 100, supra note 4, §§ 2(a)(1), (a)(7).

107. 426 U.S. 833 (1976).

108. Id. at 852 .

109. 469 U.S. 528 (1985).

110. Id. at 556 .

111. Id. at 552 .

112. Id. at 554 .

113. In his dissent, Justice (now Chief Justice) Rehnquist "confident[ly]" expressed the view that the principles of National League of Cities would "in time again command the support of a majority of this Court." Id. at 580. Justice O'Connor, joined by Justice Powell, also predicted that National League of Cities would someday be resurrected. Id. at 589 (dissenting opinion). 
cause such a grant would affect only state judiciaries, and would not in any way impair the ability of the states to influence the national political process. ${ }^{114}$

Furthermore, the constitutionality of transfer to state courts is all but compelled by a line of cases holding that under the supremacy clause, ${ }^{115}$ a state court may be required by federal law to hear a federal cause of action if the court is empowered to entertain analogous claims based upon state law. ${ }^{116}$ In Testa $v$. Katt, ${ }^{117}$ the Supreme Court unanimously held that a state court could not refuse to entertain a treble damages action brought under federal wartime price control legislation. Under the supremacy clause, stated the Court, "a state court cannot 'refuse to enforce the right arising from the law of the United States because of conceptions of impolicy or want of wisdom on the part of Congress in having called into play its lawful powers." "118 Because the Rhode Island court in Testa had the jurisdiction to adjudicate "this same type of claim [had it] aris[en] under Rhode Island law,"119 the state court was obliged to hear claims under the federal price control law. ${ }^{120}$ Similarly, a state court could not constitutionally refuse to hear a state law claim transferred to it by the Judicial Panel because such a claim could be viewed as a federal claim that is analogous to, and involves the application of, state law. ${ }^{121}$

The Court's decision in Testa recently received an expansive affirmation in FERC $v$. Mississippi, ${ }^{122}$ in which the Court rejected an attack on what it conceded to be an "intrusive" legislative scheme designed to enable

114. Cf. Rapaczynski, From Sovereignty to Process: The Jurisprudence of Federalism After Garcia, 1985 Sup. CT. REv. 341, 364-66, 414-19 (arguing that Garcia leaves room for judicial invalidation of federal actions that would undermine role of states in national political process).

115. U.S. CONST. art. VI.

116. FERC v. Mississippi, 456 U.S. 742, 760-61 (1982); Testa v. Katt, 330 U.S. 386, 393-94 (1947); see Redish \& Muench, Adjudication of Federal Causes of Action in State Court, 75 Mich. L. REv. 311, 340-46 (1976).

117. 330 U.S. 386 (1947).

118. Id. at 393 (quoting Minneapolis \& St. Louis R.R. v. Bombolis, 241 U.S. 211, 222 (1916)).

119. Id. at 394 .

120. Id. ("Under these circumstances the State courts are not free to refuse enforcement of petitioners' claim.").

121. It would not be unprecedented for a state court to hear a federal claim based upon state law. Under the Outer Continental Shelf Lands Act (OCSLA), 43 U.S.C. $\$ \S 1330-1356$ (1982 \& Supp. II 1985), "the civil and criminal laws of each adjacent State . . . are declared to be the law of the United States for that portion of the subsoil and seabed of the outer Continental Shelf . . . which would be within the area of the State if its boundaries were extended seaward to the outer margin of the . . Shelf . . . " 43 U.S.C. $\S 1333(\mathrm{a})(2)(\mathrm{A})$ (1982). Thus, in personal injury actions arising from events above the seabed of the Continental Shelf, OCSLA "incorporates as federal law . . . the laws of the State adjacent to the scene." Guif Offshore Co. v. Mobil Oil Corp., 453 U.S. 473, 477 (1981). Because the Supreme Court has held that state and federal courts have concurrent jurisdiction over OCSLA claims, id. at 484, it would appear that under Testa (which also involved a federal cause of action over which state and federal courts had concurrent jurisdiction), state courts cannot refuse to adjudicate OCSLA disputes.

122. 456 U.S. 742 (1981). 


\section{Multistate Litigation in State Courts}

"the Federal Government . . . to use state regulatory machinery to advance federal goals." ${ }^{\text {"123 }}$ FERC involved a constitutional challenge brought by Mississippi authorities to provisions of the Public Utility Regulatory Policies Act of $1978^{124}$ (PURPA), through which Congress sought to encourage the conservation of oil and natural gas by electric utilities. Relying on Testa, the Court in FERC upheld a provision of PURPA requiring certain quasi-judicial state regulatory agencies to adjudicate disputes arising under the Act or under implementing regulations promulgated by the Federal Energy Regulatory Commission. ${ }^{125}$ In addition, the Court upheld provisions of PURPA that required state regulatory commissions to consider, under federally prescribed procedures, the adoption of an extensive array of regulatory standards set forth in the statute and designed to promote the efficient use of energy resources. ${ }^{128}$ Interpreting the Testa decision as "reveal[ing] that the Federal Government has some power to enlist a branch of state government-there the judiciary - to further federal ends," ${ }^{\prime 27}$ the Court held that PURPA's requirement that states consider the adoption of federal standards did not violate the Constitution because the federal law did not " 'directly compel[]" the States to enact a legislative program." 228 The Court emphasized that PURPA neither "threaten[ed] the States' 'separate and independent existence" "129 nor "impair[ed] the ability of the States 'to function effectively in a federal system," "130 but instead "offered the States a vehicle for remaining active"131 in an area that could be wholly preempted by federal law.

FERC strongly supports the constitutionality of a system of federally coordinated transfers of multistate litigation to state courts, and suggests that such a system would even survive an attack under National League of Cities. ${ }^{132}$ Like PURPA, this Note's proposal would not "directly compel" states to enact legislation of any sort. The proposal set forth in this

123. Id. at 759 .

124. Pub. L. No. 95-617, 92 Stat. 3117 (1978) (codified in scattered sections of 15 and 16 U.S.C.).

125. 456 U.S. at 758-61. All members of the Court concurred on this point. See id. at 775 (Powell, J., concurring in part), 775-76 n.1 (O'Connor, J., concurring in judgment in part and dissenting in part).

126. Id. at 761-70. Only five justices voted to uphold these provisions.

127. Id. at 762 (footnote omitted).

128. Id. at 765 .

129. Id. (quoting Lane County v. Oregon, 74 U.S. (7 Wall.) 71,76 (1869)).

130. Id. at 765-66 (quoting National League of Cities v. Usery, 426 U.S. 833, 852 (1976)).

131. Id. at 766 .

132. See supra note 113. Nevertheless, because the majority in FERC later became the majority in Garcia v. San Antonio Metropolitan Transit Authority, 469 U.S. 528 (1985), any future abandonment of Garcia would cast doubt upon the precedential value of FERC's approval of the provisions in PURPA governing mandatory consideration of regulatory standards by the states. In any event, the demise of Garcia would not likely disturb Testa, see supra note 125, and would thus leave an ample basis for the constitutional defense of the proposal set forth in this Note. See supra notes 115-21 and accompanying text. 
Note would neither threaten "the States' 'separate and independent existence" " nor in any way "directly impair" the ability of states to "structure integral operations in areas of traditional governmental functions." 133 In particular, the Judicial Panel would be required to refrain from exercising its authority in a fashion that would unduly burden individual state courts. ${ }^{134}$ Moreover, in the aggregate, the proposal would not unduly burden state judiciaries because the number of cases that would be assigned to state courts by the Judicial Panel would represent only a tiny fraction of the overall workload of state judiciaries. Indeed, it is widely believed that even a substantial curtailment of diversity jurisdiction would only minimally enlarge state court caseloads. ${ }^{135}$ Because complex multidistrict litigation accounts for only a small portion of diversity cases, ${ }^{136}$ consolidation of such litigation in state courts could not on the whole greatly burden state judiciaries. ${ }^{137}$

The proposal set forth in this Note would enhance rather than impair the authority of the states. By guaranteeing state courts a role in the adjudication of multistate, multiparty disputes, the proposal would "offer the States a vehicle for remaining active in an area of overriding concern."138 Indeed, the policies reflected in the proposal resemble the values motivating the judicially created abstention doctrines, which have become an important part of the legal landscape of federalism. For example, under the abstention doctrine set forth in Colorado River Water Conservation District v. United States, ${ }^{139}$ the Supreme Court has permitted federal district

133. National League of Cities, 426 U.S. at 852.

134. See supra notes 53-67 and accompanying text.

135. See, e.g., Diversity Hearings, supra note 69, at 203-04 (statement of Professor Charles Alan Wright); ALI STUdy, supra note 36, at 473-74; R. POSNER, The Federal Courts 134, 181 \& n.17 (1985); Bork, supra note 42, at 237 ("abolition of diversity jurisdiction . . . would increase [state court] dockets apparently only by about 1.5 percent"); Burdick, Diversity Jurisdiction Under the American Law Institute Proposals: Its Purpose and Its Effect on State Courts, 48 N.D.L. REv. 1,18 (1971) (shifting approximately half of all diversity litigation to state courts "would only slightly increase the number of cases per state trial judge"); Flango \& Blair, The Relative Impact of Diversity Cases on State Trial Courts, STATE Cr. J., Summer 1978, at 20, 24 (elimination of diversity jurisdiction and transfer of diversity cases to state courts "would be handled in most instances without major additions to state judicial resources" but "would impose a disproportionate hardship on some states"); Sheran \& Isaacman, supra note 39, at 61-68.

136. In 1983, for example, the Panel ordered the transfer of 687 civil actions for consolidated proceedings with 528 actions already pending in transferee districts. ANNUAL REPORT 1985, supra note 53, at 168 .

137. In assessing the burden that this Note's proposal would place on state courts, it must also be remembered that not all complex multistate litigation would be consolidated in state courts. See supra notes 54-65 and accompanying text.

138. FERC v. Mississippi, 456 U.S. 742,766 (1982).

139. 424 U.S. 800 (1976). Although the Supreme Court has not referred to the rule of Colorado River as an "abstention" doctrine, see Moses H. Cone Hosp. v. Mercury Constr. Corp., 460 U.S. 1, 14 (1982), commentators have labeled it as such. See, e.g., C. WRIGHT, Federal CourTS $\S 52$, at 317-19 (4th ed. 1983); Redish, Abstention, Separation of Powers, and the Limits of the Judicial Function, 94 YALE L.J. 71, 96 (1984). 
courts to dismiss federal suits in deference to state proceedings when such a dismissal would promote judicial economy. Specifically, the Court in Colorado River, affirming the dismissal of a lawsuit brought by the United States against more than 1,000 defendants, stated that considerations of "wise judicial administration, giving regard to conservation of judicial resources and comprehensive disposition of litigation," could, under some circumstances, "permit[] the dismissal of a federal suit due to the presence of a concurrent state proceeding." ${ }^{140}$ In determining whether dismissal is warranted, a district court may consider "such factors as the inconvenience of the federal forum, . . . the desirability of avoiding piecemeal litigation,"141 and the involvement of rights determined by state law. ${ }^{142}$

Colorado River reflects a recognition by the Supreme Court that, in cases in which rights determined by state law are at stake, consolidated adjudication in state court may be preferable to parallel litigation in state and federal courts. The Court's willingness in Colorado River to allow in effect a substantial transfer of litigation from a federal to a state court-without any mention of possible administrative burdens that the state court might suffer as the result of abstention-suggests that the Court assumed that the federalistic benefits of having a state court adjudicate state-created rights outweighed any such administrative burdens. Similarly, any burden that might result from the proposal set forth in this Note would be justified by the fact that the added burden faced by state courts would be that of interpreting and administering their own law.

\section{Gonclusion}

By expanding the power of the Judicial Panel on Multidistrict Litigation to permit the Panel to transfer cases both to and from state courts, Congress could substantially limit the potential for inefficient and inconsistent adjudication in complex multistate litigation. Moreover, through the selective use of the power to direct the consolidation of multistate litigation in state courts, the Panel could foster the growth and development of state law, while enabling more federal judicial resources to be devoted to the articulation and enforcement of federal law. Extension of the Judicial Panel's authority would thus promote the development of a more efficient and more specialized judicial structure that would be better suited to meet the nation's needs.

140. 424 U.S. at $817-18$ (citations omitted).

141. Id. at 818 (citations omitted).

142. Id. at 819 . The federal and state suits primarily concerned water rights governed by Colorado law. Id. at 804-05. 